ISSN 1392-3196 / e-ISSN 2335-8947

Zemdirbyste-Agriculture, vol. 103, No. 4 (2016), p. 385-390

DOI 10.13080/z-a.2016.103.049

\title{
Effect of water deficit on yield and quality of lemon balm (Melissa officinalis L.)
}

\author{
Péter RADÁCSI, Krisztina SZABÓ, Dóra SZABÓ, Eszter TRÓCSÁNYI, \\ Éva NÉMETH-ZÁMBORI
}

Szent István University

Villányi 29-43, Budapest, Hungary

E-mail: radacsi.peter@kertk.szie.hu

\begin{abstract}
The aim of the present study was to investigate the effect of the level and timing of watering on the productivity and chemical constituents of lemon balm (Melissa officinalis L. cv. 'Soroksár'). As control 70\% soil water capacity was set. In treatments stress 1 and stress 2 the soil water capacity decreased stepwise from $70 \%$ to $30 \%$ and sharply from $70 \%$ to $30 \%$, respectively. In the strongest and permanent water deficit treatment stress $330 \%$ soil water capacity was applied. Among the production parameters the water deficit reduced the plant height, bush diameter, fresh and dry mass of the plants. Besides, the root:shoot ratio increased, while in the root length, fresh and dry mass no significant differences were detected. Water deficit also influenced the phenolic compounds. Under stress1 and stress 2 circumstances decreased accumulation of flavonoids (by 14-22\%) was observed while the drought conditions resulted in enhancement in the rosmarinic acid concentration (1-22\% compared to the control). The highest antioxidant capacity $\left(201 \mathrm{mg}\right.$ ascorbic acid equivalent $\mathrm{g}^{-1}$ dry mass) and total phenolic content (178 mg gallic acid equivalent $\mathrm{g}^{-1}$ dry mass) were measured in treatment stress 3 where permanent $30 \%$ soil water capacity was applied, while the stress 2 plants produced the lowest antioxidant capacity $(66 \mathrm{mg}$ ascorbic acid equivalent $\mathrm{g}^{-1}$ ) and total phenolic content (105 mg gallic acid equivalent $\mathrm{g}^{-1}$ ). The gradually decreasing water supply did not modify antioxidant capacity and total phenolic content. The results show that not only the level of water deficit, but its timing and dynamics may have significant effects on the quantity and quality of lemon balm production.
\end{abstract}

Key words: antioxidant capacity, drought, flavonoid, medicinal plant, rosmarinic acid, total phenolic content, water deficit.

\section{Introduction}

Lemon balm (Melissa officinalis L.) is a widely known perennial, herbaceous plant. It is native to the Mediterranean region, but it is cultivated all over the world. It contains valuable essential oil $(0.05-0.52 \%)$ which may be responsible for sedative, carminative, antispasmodic, antibacterial and antiviral properties of the herb (Sari, Ceylan, 2002; Patora et al., 2003; SeidlerŁożykowska et al., 2013; Nasab et al., 2015). However, nowadays the focus of research has been shifted to phenolic compounds which may also contribute to several advantageous therapeutical properties (Tóth et al., 2003; Mimica-Dukic et al., 2004; Dias et al., 2012). The increasing interest in phenolic compounds is obvious also from the requirements of the Pharmacopoeia Europaea VIII (2013) where the concentration of total hydroxycinnamic derivatives - expressed as rosmarinic acid - is the main quality parameter.

Rosmarinic acid as the major phenolic component of lemon balm usually accumulates between $2 \%$ and $4 \%$ of dry mass (DM) (Carnat et al., 1998; Barros et al., $2013)$, but in some cases even a higher level $(9.6 \%)$ was identified (Dastmalchi et al., 2008). The total flavonoid content is usually between $0.1 \%$ and $1 \%$ (Carnat et al., 1998; Stefanovic, Comic, 2012; Duda et al., 2015), while the total phenolic content varies in a wide range between $20 \mathrm{mg}$ GAE (gallic acid equivalent) g ${ }^{-1}$ DM (Saeb et al., 2011) and $319 \mathrm{mg} \mathrm{GAE} \mathrm{g}^{-1}$ of water extract (Stefanovic, Comic, 2012).

In Central European area, precipitation seems to bethe primaryyield limiting factor formost of the cultivated crops. Among a large number of publications evaluating the effects of drought on Lamiaceae species there are only a few dealing with M. officinalis (Munné-Bosch, Alegre, 1999; Ozturk et al., 2004; Abbaszadeh et al., 2009; Ahl et al., 2009; Farahani et al., 2009; Manukyan, 2011; Nasab et al., 2015). It has been demonstrated that lower water availability results in reduced biomass and some morphological characteristics (plant height, diameter, branch number, etc.) may also significantly decrease. According to the above mentioned publications, drought may slightly enhance the concentration of essential oil, while the essential oil yield always decreases. Although phenolics may be the most important active ingredients of lemon balm, hardly any data have been published about their variability due to environmental effects. The only reference dealing with this issue reported a significant increase in each of the polyphenols and rosmarinic acid together with a higher antioxidant capacity of lemon balm leaves due to decreasing substrate moisture (Manukyan, 2011). Additionally, there is a lack of data on the changing water supply although in nature periods rich and poor in precipitation may come randomly one after another. In the last 30 years, the average temperature of Hungary increased by $1.7^{\circ} \mathrm{C}$. While in the last hundred years $7 \%$ less natural precipitation has occurred. Forecasts also predict the reduction in the number of wet days (Bartholy et al., 2011). Lemon balm is known in the cultivation practice as a moisture requiring species (Szabó, Lenchés, 2013).

Therefore, the goal of this study was to gain a deeper insight into the effects of water deficit on lemon 
balm under controlled conditions simulating variable conditions of water supply. In practice, the study may contribute to the accumulation of relevant information on the consequences of water supply concerning quantity and quality of lemon balm production.

\section{Materials and methods}

Plant material. Lemon balm (Melissa officinalis L.) cv. 'Soroksár' purchased from a nursery in 2009 and maintained at Research Station in Budapest, Hungary. Seedlings were grown in May of 2014 from seeds in a greenhouse at the research station of the department and one plant per pot was planted at growth stage (GS) 118, based on the general BBCH scale (Hack et al., 1992) in pots for the experiment.
Growth conditions. During the experiment, plants were grown in pots in a growth chamber WeissGallenkamp SGC-120 (Weiss Technik UK Ltd., UK). The medium was a soil mixture Florasca Bio "B" (Florasca Ltd., Hungary) consisting of $10 \%$ sand, $65 \%$ peat from the Fertő-Hanság area, Hungary, and $25 \%$ cattle manure compost. Characteristics of the medium are summarized in Table 1. Each pot was filled an equal mass of $4.8 \mathrm{~kg}$.

The conditions in the climate chamber were as follows: in the first 5 weeks $22 / 15^{\circ} \mathrm{C}$ (day/night temperatures) and 20000 lux illumination for 12 hours day ${ }^{-1}$. In the following 8 weeks $25 / 16^{\circ} \mathrm{C}$ (day/ night temperatures) and 20000 lux illumination for 14 hours day ${ }^{-1}$ were maintained. Air relative humidity was $50 \%$ throughout the study. The plants were evaluated, harvested and sampled after the 13 weeks' experimental

Table 1. Characteristics of the soil mixture Florasca Bio "B"

\begin{tabular}{|c|c|c|c|c|c|c|}
\hline $\begin{array}{c}\mathrm{pH} \\
6.79 \\
\end{array}$ & $\begin{array}{c}\text { Salt } \\
0.68 \%\end{array}$ & $\begin{array}{c}\text { Humus } \\
12.30\end{array}$ & $\begin{array}{c}\mathrm{NO}_{3}-\mathrm{N} \\
45.30 \mathrm{mg} \mathrm{kg}^{-1}\end{array}$ & $\begin{array}{c}\mathrm{P}_{2} \mathrm{O}_{5} \\
357.00 \mathrm{mg} \mathrm{kg}{ }^{-1}\end{array}$ & $\begin{array}{c}\mathrm{K}_{2} \mathrm{O} \\
1270.00 \mathrm{mg} \mathrm{kg}^{-1}\end{array}$ & $\begin{array}{l}\mathrm{Ca} \\
1.98 \%\end{array}$ \\
\hline $\begin{array}{c}\mathrm{Mg} \\
170.00 \mathrm{mg} \mathrm{kg}{ }^{-1}\end{array}$ & $\begin{array}{c}\mathrm{Fe} \\
159.00 \mathrm{mg} \mathrm{kg}^{-1}\end{array}$ & $\begin{array}{c}\mathrm{Mn} \\
7.37 \mathrm{mg} \mathrm{kg}^{-1}\end{array}$ & $\begin{array}{c}\mathrm{Zn} \\
8.03 \mathrm{mg} \mathrm{kg}^{-1}\end{array}$ & $\begin{array}{c}\mathrm{Cu} \\
4.88 \mathrm{mg} \mathrm{kg}^{-1}\end{array}$ & $\begin{array}{c}\mathrm{B} \\
6.29 \mathrm{mg} \mathrm{kg}^{-1}\end{array}$ & $\begin{array}{c}\mathrm{CaCO}_{3} \\
<1 \%\end{array}$ \\
\hline
\end{tabular}

period when the plants were in the phenological stage 551 based on the general BBCH scale (Hack et al., 1992).

Treatments. Four different water supply treatments were installed: control (C) plants were grown in soil with a 70\% saturation level of soil water capacity (SWC) (Table 2). In treatment stress1 the SWC was decreased gradually from $70 \%$ to $30 \%$. Plants of treatment stress 2 were grown under $70 \%$ SWC, but at the end of the experiment (for the last 4 weeks) water content was suddenly decreased to $30 \%$ SWC. For modelling severe drought conditions, a permanent water level of $30 \%$ SWC was applied in the treatment stress3. Five pots per treatments were installed. SWC was determined using the modified gravimetric method of Reynolds (1970) based on the water holding capacity of the soil. The plants were irrigated by measuring the pot weight and filling the pots to a formerly identified weight three times per week. Soil surface in the pots was covered with aluminium foil in order to prevent evaporation and to calculate water use.

Morphologicalcharacteristics. Shortlybeforethe harvest the most important morphological characteristics were recorded. Plant height was measured as the length of the longest shoot from the root neck to the tip of the shoot. In line with this, root length was determined as a distance between the root neck and the tip of the longest root. Plant diameter was measured as a natural horizontal

Table 2. The experimental design and description of treatments

\begin{tabular}{|c|c|c|c|c|c|}
\hline \multirow{2}{*}{\multicolumn{2}{|c|}{ Time (weeks) }} & \multicolumn{4}{|c|}{ Soil water capacity (SWC) of the treatments $\%$} \\
\hline & & \multirow{2}{*}{$\begin{array}{c}\text { control } \\
70\end{array}$} & \multirow{2}{*}{$\begin{array}{c}\text { stress } 1 \\
70\end{array}$} & \multirow{2}{*}{$\begin{array}{c}\text { stress } 2 \\
70\end{array}$} & \multirow{2}{*}{$\begin{array}{c}\text { stress3 } \\
70\end{array}$} \\
\hline Acclimatization & (4 weeks) & & & & \\
\hline Stress treatments & $\begin{array}{c}1-5(5 \text { weeks }) \\
6-9(4 \text { weeks }) \\
10-13(4 \text { weeks })\end{array}$ & $\begin{array}{l}70 \\
70 \\
70 \\
\end{array}$ & $\begin{array}{l}70 \\
60 \\
30 \\
\end{array}$ & $\begin{array}{l}70 \\
70 \\
30 \\
\end{array}$ & $\begin{array}{l}30 \\
30 \\
30 \\
\end{array}$ \\
\hline
\end{tabular}

expansion of the shoots. Besides, the number of main shoots was determined. These measurements were carried out in 4-5 replicates per treatment.

Leaf surface was determined at the $3^{\text {rd }}$ internode from the tip of the shoot. Leaves were scanned with a blue sheet $(14.85 \times 21 \mathrm{~cm})$ as background. In software Adobe Photoshop CS3 the pixel number of the blue sheet was determined. Leaves were selected with tool Magic Wand with the threshold 30. In the histogram the pixel number of the selected area was read. Based on the ratio of the surface and the pixel number, the leaf surface was identified. Fifteen replicates per treatment were measured.

Productivity. Immediately after lifting the plants from the pots, fresh mass of both shoots and roots was measured for each individual. The samples were dried at room temperature to a constant weight and the dry mass was determined. These measurements were carried out in five replicates per treatment. Pot weights were measured and registered to calculate the total water use (WU) of the plants. Based on the dry weight of the shoots, roots and the WU the water use efficiency of shoots (WUE) and roots $\left(\mathrm{WUE}_{\mathrm{f}}\right)$ were calculated as follows: $\mathrm{WUE}=$ shoot or root $\mathrm{DM} / \mathrm{WU}$.

Phytochemical measurements. After drying, all harvested individual shoot samples were mixed creating a bulk sample for each treatment. Thick stem parts making up the lower two-third of the shoots were eliminated from the samples in order to ensure the proper powder state during grinding, practically resulting in Melissae folium (lemon balm leaf) powder. From the homogeneous bulk sample three biological replicates were made.

Total phenolic content. For the total phenolic content measurement $1 \mathrm{~g}$ dried and powdered plant material was extracted by $100 \mathrm{~mL}$ hot distilled water and was allowed to stand for $24 \mathrm{~h}$. Then the extracts were filtered and stored in a freezer until use. The total phenolic content was determined by the modified method of Singleton and Rossi (1965). The sample solution $(0.5 \mathrm{~mL})$ was introduced into a test tube and then $2.5 \mathrm{~mL}$ of Folin-Ciocalteau's reagent $(10 \mathrm{v} / \mathrm{v} \%$ ) was added. After incubation for $1 \mathrm{~min}, 2 \mathrm{~mL}$ of sodium carbonate $(0.7 \mathrm{M})$ was added. The absorbance was measured at $760 \mathrm{~nm}$ in a spectrophotometer Thermo Evolution 201 (Thermo Fisher Scientific, USA) after incubation for $5 \mathrm{~min}$ in hot water $\left(50^{\circ} \mathrm{C}\right)$. Gallic acid $(0.3 \mathrm{M})$ was used as chemical standard for calibration. The total phenolic content of the sample was expressed as gallic acid equivalent (GAE) per dry weight of extract. Blank was prepared to contain distilled water instead of extract. From the harvested individuals three representative bulk samples were prepared. Each analysis was repeated three times.

Flavonoid content was determined according to the method given in Pharmacopoeia Hungarica VIII (2004) for "Equiseti herba" using half of the amounts of materials described there. Shortly, $0.4 \mathrm{~g}$ dried and powdered plant material was extracted by $1 \mathrm{~mL}$ 
hexametilentetramine, $20 \mathrm{~mL}$ acetone and $2 \mathrm{~mL} \mathrm{HCl}$ for $30 \mathrm{~min}$ and then it was filtered. Afterwards the extraction was repeated by $20 \mathrm{~mL}$ acetone twice and diluted by water and ethyl-acetate. The absorbance was measured at $760 \mathrm{~nm}$ in the spectrophotometer mentioned above after incubation for $30 \mathrm{~min}$ and expressed in isoquercitroside (QE) per dry weight of plant material. Blank was prepared from acetic acid and methanol. The measurements were carried out in three replicates/treatment.

Rosmarinic acid content was determined based on the Pharmacopoeia Europea VIII (2013). To prepare the extracts, $500 \mathrm{~g}$ powdered dry plant material was suspended in $45 \mathrm{~mL}$ methanol. The suspension was heated for $30 \mathrm{~min}$ in a water bath, then it was cooled and finally filtered (by $45 \mu \mathrm{m}$ filter) into a $100 \mathrm{~mL}$ flask. The filtrate was completed by the same solvent (methanol) to a volume of $50.0 \mathrm{~mL}$. Rosmarinic acid content was determined by the high-performance liquid chromatography (HPLC) method. The Waters HPLC system consisted of a 1525 binary pump with a 717 plus autosampler, a Jetstream column thermostat and a 2998 Photodiode Array detector controlled by software Empower2. A column Kinetex C-18 was used, 100 $\mathrm{mm}$ L $4.6 \mathrm{~mm}$ internal diameter, $2.6 \mu \mathrm{m}$ particle size. All solvents were HPLC grade. For the elution, 1:19:80 phosphoric acid:acetonitrile:water (mobile phase A) and 1:40:59 phosphoric acid:methanol:acetonitrile (mobile phase B) were used as solvents at a flow rate of $1 \mathrm{~mL} \mathrm{~min}^{-1}$ based on the Pharmacopoeia Europaea (2013) section VIII about Melissae folium. The gradient program started at $100 \% \mathrm{~A}$ and after solvent B was increased linearly and reached $35 \%$ at $10 \mathrm{~min}$, then $100 \%$ at $2 \mathrm{~min}$. Finally, $100 \%$ A was reached at 2 min. Eight min post-time was set for the equilibration of the initial solvent composition. The column temperature was maintained at $35^{\circ} \mathrm{C}$ and the injection volume of $5 \mu \mathrm{l}$ was used in all experiments. Antioxidant capacity. The ferric reducing antioxidant power (FRAP) assay was performed according to the Benzie and Strain (1996) procedure with slight modifications. One gram dried and powdered plant material was extracted by $100 \mathrm{~mL}$ hot distilled water and was allowed to stand for $24 \mathrm{~h}$. Then the extracts were filtered and stored in freezer until use. FRAP reagent was prepared freshly to contain sodium acetate buffer $(\mathrm{pH}$ 3.6), TPTZ (2,4,6-tripiridil-s-triazin) in $\mathrm{HCl}$ and $\mathrm{FeCl}_{3} \times 6 \mathrm{H}_{2} \mathrm{O}$ solution $\left(20 \mathrm{mmol} \mathrm{L}^{-1}\right)$ in a proportion of $10: 1: 1(\mathrm{v} / \mathrm{v} / \mathrm{v})$, respectively. Ten $\mu \mathrm{L}$ of test sample was added to $1.5 \mathrm{~mL}$ of FRAP reagent and $40 \mu \mathrm{L}$ distilled water and absorbance was recorded at $593 \mathrm{~nm}$ after 5 min using the spectrophotometer indicated above. Blank was prepared to contain distilled water instead of extract. FRAP values of samples were calculated from standard curve equation and expressed as ascorbic acid equivalent (AAE) per dry extract. From the harvested individuals three representative bulk samples were prepared. Each analysis was repeated three times.

Statistical analysis. The results were analysed with a statistical program IBM SPSS 22.0. One-way $A N O V A$ was applied. Depending on the homogeneity of variances, Tukey HSD or Games-Howel test was used for the pair-wise comparisons of the variances. Confidence level was $5 \%$. The linear regressions between variables were tested with Pearson correlation.

\section{Results and discussion}

Morphology and production. Water supply modified the morphological parameters of lemon balm (Table 3 ). The plant height varied between 30.00 and $40.75 \mathrm{~cm}$. It was significantly lower in the plants which were grown under continuous low water supply (stress3) while the control treatments stress 1 and stress2 did not differ from each other. This means that only the long term drought had a major reduction effect on the height. Ozturk et al. (2004) and Abbaszadeh et al. (2009) reported decreasing plant height (from 57 to $46 \mathrm{~cm}$ ) in drought conditions. Similar tendency was observed in the plant diameter where the lowest value was also measured in treatment stress $3(34.50 \mathrm{~cm})$. Conversely, plants of the largest bush diameter were grown in the control treatment $(49.00 \mathrm{~cm})$. However, neither of these studies applied different dynamics of water supply similarly to our stress 1 and stress 2 conditions.

Water shortage reduced the number of branches, as well (Table 3$)$. The highest branch number $(26.50 \mathrm{pcs}$ plant $^{-1}$ ) was detected in the control treatment while the number of branches decreased in the stress treatments. The lowest branch number was measured in stress 3 , which was only $56 \%$ of that of the value measured in the control plants. The above mentioned Ozturk et al. (2004) and Abbaszadeh et al. (2009) also reported a decline of branch number due to water shortage, but even under the most severe deficit conditions the reduction was less than $30 \%$. According to our results, the length of internodes was between 2.50 $2.65 \mathrm{~cm}$ and it was not modified by the water supply.

The continuous shortage of water resulted in a reduced leaf surface in stress 3 plants. Leaf surfaces of control and stress 2 treatments were $100-150 \mathrm{~mm}^{2}$ bigger than those in treatments stress 1 and stress 3 (Table 3 ). This means that a gradual reduction of water supply may also lead to the development of smaller leaves to reduce transpiration. Formerly Ahl et al. (2009) observed more than $70 \%$ decrease in the leaf area of drought stressed plants ( $40 \%$ available soil moisture) compared to the control plants ( $80 \%$ available soil moisture), although the conditions are hardly comparable to those of the present experiment.

Decreased water supply had significant effect on the biomass and on the dry mass of the plants (Table 3 ). Control plants had almost 3-fold higher biomass $(67.97 \mathrm{~g}$ plant $^{-1}$ ) than the ones grown in drought conditions (stress 3 , $23.34 \mathrm{~g} \mathrm{plant}^{-1}$ ). The reduced water supply influenced the biomass also in the cases when stress treatment started in later phases of development. Thus, the treatments of stress 1 and stress 2 showed no significant difference from the values obtained in treatment stress 3 with continuous stress conditions. The same tendency is obvious in the case of dry mass. This means that in the cultivation practice a shorter dry period before harvest might also lead to sever yield reduction of lemon balm compared to the situation when there is a longer drought throughout the growing period. Our results are comparable with all the previous studies where intensive reduction in fresh and dry mass of lemon balm was reported as a result of the lack of water (Ozturk et al., 2004; Abbaszadeh et al., 2009; Manukyan, 2011). However, there has been no information till now about the effects of periodical drought occurring frequently in nature. A significant positive correlation was observed between plant height and shoot mass $(r=0.619, p=0.011)$ as well as between bush diameter and mass $(r=0.555, p=0.026)$.

Unlike the aboveground parts, fresh and dry mass of roots were not significantly modified by the water supply (Table 3). The fresh mass varied between 16.96 and $27.40 \mathrm{~g}$ plant $^{-1}$ while the dry mass was measured between 3.11 and $3.89 \mathrm{~g} \mathrm{plant}^{-1}$. It was observed that control plants had almost $15 \%$ longer roots than the stressed ones (stress1, stress 2 and stress3). After calculating the root:shoot ratio we found that in the treatment stress 3 it was almost the double of that of the control (Table 3). The ratio 0.640 obtained in the permanent stress treatment (stress 3 ) was significantly higher than each of the ratios obtained in the other treatments $(0.347-0.423)$. This shows that a longer dry period stimulated the plants to develop a higher root mass. This phenomenon is known for several species (Valdez, 2014), but has not been described in lemon balm till now.

The results showed that water use of the experimental plants was different. The control plants used more than the double amount of water compared to 
Table 3. Effect of different water supply on the morphological characteristics and productivity of Melissa officinalis (mean \pm standard deviation)

\begin{tabular}{|c|c|c|c|c|c|}
\hline \multirow{2}{*}{ Trait } & \multicolumn{4}{|c|}{ Treatment } & \multirow{2}{*}{$\begin{array}{c}\text { Statistics } \\
\text { (F probe, } p \text { value, } \\
\text { post hoc test) } \alpha=0.05\end{array}$} \\
\hline & control & stress 1 & stress2 & stress 3 & \\
\hline $\begin{array}{c}\text { Plant height } \\
\mathrm{cm}\end{array}$ & $39.00 \mathrm{ab} \pm 7.35$ & $37.50 \mathrm{ab} \pm 3.31$ & $40.75 \mathrm{a} \pm 4.57$ & $30.00 \mathrm{~b} \pm 1.82$ & $\begin{array}{c}\mathrm{F}(3 ; 12)=4.014, \\
p=0.034, \text { Tukey HSD }\end{array}$ \\
\hline $\begin{array}{l}\text { Plant diameter } \\
\mathrm{cm}\end{array}$ & $49.00 \mathrm{a} \pm 4.08$ & $42.50 \mathrm{a} \pm 3.32$ & $42.50 \mathrm{a} \pm 3.42$ & $34.50 \mathrm{~b} \pm 3.11$ & $\begin{array}{c}\mathrm{F}(3 ; 12)=11.503, \\
p=0.001, \text { Tukey HSD }\end{array}$ \\
\hline $\begin{array}{l}\text { Fresh shoot mass } \\
\text { g plant }^{-1}\end{array}$ & $67.97 \mathrm{a} \pm 21.58$ & $40.82 b \pm 7.03$ & $42.24 b \pm 11.64$ & $23.34 b \pm 6.11$ & $\begin{array}{c}\mathrm{F}(3 ; 14)=9.270, \\
p=0.001, \text { Tukey HSD }\end{array}$ \\
\hline $\begin{array}{c}\text { Number of branches } \\
\text { pes }\end{array}$ & $26.50 \mathrm{a} \pm 5.51$ & $19.25 \mathrm{ab} \pm 2.06$ & $18.00 \mathrm{~b} \pm 2.94$ & $15.00 \mathrm{~b} \pm 2.16$ & $\begin{array}{c}\mathrm{F}(3 ; 12)=7.950, \\
p=0.003, \text { Tukey HSD }\end{array}$ \\
\hline $\begin{array}{l}\text { Internode length } \\
\mathrm{cm}\end{array}$ & $2.50 \mathrm{a} \pm 0.48$ & $2.65 \mathrm{a} \pm 0.29$ & $2,57 \mathrm{a} \pm 0.15$ & $2.55 \mathrm{a} \pm 0.30$ & $\begin{array}{c}\mathrm{F}(3 ; 12)=0.148 \\
\quad p=0.929\end{array}$ \\
\hline $\begin{array}{l}\text { Leaf surface } \\
\mathrm{mm}^{2} \text { leaf }^{-1}\end{array}$ & $775.99 \mathrm{a} \pm 143.92$ & $689.72 \mathrm{a} \pm 178.06$ & $793.04 \mathrm{a} \pm 248.38$ & $605.16 \mathrm{a} \pm 223.90$ & $\begin{array}{c}\mathrm{F}(3 ; 56)=2.741 \\
p=0.052\end{array}$ \\
\hline $\begin{array}{l}\text { Dry shoot mass } \\
\text { g plant }^{-1}\end{array}$ & $11.12 \mathrm{a} \pm 4.67$ & $9.22 \mathrm{ab} \pm 1.11$ & $9.59 \mathrm{ab} \pm 3.08$ & $4.60 b \pm 1.48$ & $\begin{array}{c}\mathrm{F}(3 ; 14)=4.953, \\
p=0.015, \text { Tukey HSD }\end{array}$ \\
\hline $\begin{array}{l}\text { Fresh root mass } \\
\text { g plant }^{-1}\end{array}$ & $27.40 \mathrm{a} \pm 13.27$ & $20.00 \mathrm{a} \pm 3.32$ & $17.14 \mathrm{a} \pm 6.54$ & $16.96 \mathrm{a} \pm 3.62$ & $\begin{array}{c}\mathrm{F}(3 ; 14)=1.820 \\
p=0.190\end{array}$ \\
\hline $\begin{array}{l}\text { Dry root mass } \\
\mathrm{g} \mathrm{plant}^{-1}\end{array}$ & $3.84 \mathrm{a} \pm 1.44$ & $3.89 \mathrm{a} \pm 0.75$ & $3.44 \mathrm{a} \pm 1.24$ & $3.11 \mathrm{a} \pm 0.59$ & $\begin{array}{c}\mathrm{F}(3 ; 14)=0.547 \\
p=0.658\end{array}$ \\
\hline $\begin{array}{l}\text { Root lenght } \\
\mathrm{cm}\end{array}$ & $42.25 \mathrm{a} \pm 6.85$ & $36.00 \mathrm{a} \pm 4.97$ & $35.00 \mathrm{a} \pm 4.12$ & $36.80 \mathrm{a} \pm 1.79$ & $\begin{array}{c}\mathrm{F}(3 ; 12)=2.091 \\
p=0.14\end{array}$ \\
\hline $\begin{array}{l}\text { Root:shoot ratio } \\
\text { g root g shoot }\end{array}$ & $0.347 \mathrm{~b} \pm 0.015$ & $0.423 b \pm 0.074$ & $0.361 b \pm 0.052$ & $0.640 \mathrm{a} \pm 0.031$ & $\begin{array}{c}\mathrm{F}(3 ; 13), p<0.000, \\
\text { Games-Howel }\end{array}$ \\
\hline
\end{tabular}

Note. Different letters in rows are for significantly different groups.

the plants in the continuous drought (stress3) during the study period (Table 4).

According to the calculations, there is a strong positive correlation $(r=0.752, p<0.000)$ between the water use and production of dry shoot mass. Interestingly, no significant differences were detected in the water use efficiency of shoots (WUE). This indicates that the aboveground biomass production of lemon balm is largely dependent on the available and used quantity of water and the plant is not able - in the range of our experimental parameters - to improve the WUE in stress conditions. However, the WUE for root mass was elevated in the severely and continuously stressed plants. This means that they were able to produce a larger root mass by using the same amount of water. The enhanced WUE of roots is related to the elevated root/shoot ratio

Table 4. Water use and the different water use efficiency of water supply on Melissa officinalis (mean \pm standard deviation)

\begin{tabular}{|c|c|c|c|c|c|}
\hline & \multicolumn{4}{|c|}{ Treatment } & \multirow{2}{*}{$\begin{array}{c}\text { Statistics } \\
\text { (post hoc test, } \\
\text { F probe, } p \text { value) } \\
\alpha=0.05\end{array}$} \\
\hline & control & stress1 & stress2 & stress3 & \\
\hline $\begin{array}{l}\text { Water use } \\
\text { g pot }^{-1}\end{array}$ & $8562.25 \mathrm{a} \pm 1927.16$ & $6883.50 \mathrm{a} \pm 1015.55$ & $7621.00 \mathrm{a} \pm 858.44$ & $3910.00 \mathrm{~b} \pm 750.71$ & $\begin{array}{c}\text { Tukey HSD, } \\
\mathrm{F}(3 ; 13)=11.302 \\
p=0.001\end{array}$ \\
\hline $\begin{array}{l}\text { Shoot water use } \\
\text { efficiency } \\
\text { g DM g water }^{-1} 100\end{array}$ & $0.127 \mathrm{a} \pm 0.022$ & $0.135 \mathrm{a} \pm 0.014$ & $0.129 \mathrm{a} \pm 0.044$ & $0.136 \mathrm{a} \pm 0.042$ & $\begin{array}{c}\mathrm{F}(3 ; 13)=0.072 \\
p=0.974\end{array}$ \\
\hline $\begin{array}{l}\text { Root water use } \\
\text { efficiency } \\
\text { g DM g water } \\
\text { g } 100\end{array}$ & $0.044 \mathrm{~b} \pm 0.007$ & $0.057 \mathrm{ab} \pm 0.009$ & $0.046 \mathrm{~b} \pm 0.017$ & $0.087 \mathrm{a} \pm 0.025$ & $\begin{array}{c}\text { Tukey HSD, } \\
\mathrm{F}(3 ; 13)=6.085 \\
p=0.008\end{array}$ \\
\hline
\end{tabular}

Note. DM - dry mass; different letters in rows are for significantly different groups.

detected in this treatment (Table 3). In treatments stress 1 and stress 2 the shorter drought periods might not be able to induce this capacity.

Active substances. The highest total flavonoid content was measured in the control $\left(1.54 \mathrm{mg} \mathrm{GAE} \mathrm{g}^{-1}\right.$ $\mathrm{DM})$ and stress 3 (1.47 $\left.\mathrm{mg} \mathrm{GAE} \mathrm{g}^{-1} \mathrm{DW}\right)$ plants although the differences are relatively small (Table 5). Compared to these treatments, a $15-20 \%$ lower flavonoid content was measured in treatments stress 1 and stress2. To our knowledge, there are no former references on this topic. The only investigated factor in connection with flavonoids was the harvesting time, which slightly influenced the flavone and flavanole content of lemon balm; the means varied between $8-10 \mathrm{mg} \mathrm{g}^{-1}$ (Duda et al., 2015). As for other plant species, Abdelrahman et al. (2012) found a decreasing effect of drought stress on the flavonoid content of Lepidium sativum. However, in Dracocephalum moldavica the severe drought increased the flavonoid content (Halimeh et al., 2013).

The content of rosmarinic acid presented an opposite tendency: the highest values were detected in treatments stress 1 and stress $2(3.59 \%$ and $3.83 \%$, respectively) while in the control and stress 3 samples a $15-18 \%$ lower accumulation was measured (Table 5). The difference could, however, not be statistically ascertained. The data demonstrated a significant negative correlation between the flavonoid content and rosmarinic acid content $(r=-0.777, p=0.003)$. The effect of drought stress on rosmarinic acid accumulation in lemon balm has not been reported yet. In Prunella vulgaris Chen et al. (2011) measured increasing rosmarinic acid content (by 14\%) under drought conditions compared to the well-watered plants. While in Salvia miltiorrhiza the highest rosmarinic acid accumulation $(0.196 \%)$ was observed in the well-watered plants compared to drought conditions $(0.169 \%)$ (Liu et al., 2011). In the experiment we determined significant influence of the water supply both on the total phenolic content and antioxidant capacity (Table 5). The highest total phenolic content was measured in the stress 3 plants while the lowest one was present in stress 2 . Only this latter one was significantly different from the other three treatments. 
Table 5. Effect of different water supply on the phytochemical characteristics of Melissa officinalis (mean \pm standard deviation)

\begin{tabular}{|c|c|c|c|c|c|}
\hline \multirow{2}{*}{ Trait } & \multicolumn{4}{|c|}{ Treatment } & \multirow{2}{*}{$\begin{array}{c}\text { Statistics } \\
(F \text { probe, } p \text { value, } \\
\text { post hoc test }) \alpha=0.05\end{array}$} \\
\hline & control & stress 1 & stress2 & stress 3 & \\
\hline $\begin{array}{l}\text { Flavonoid content } \\
\text { mg QE g-1 DM }\end{array}$ & $1.54 \mathrm{a} \pm 0.09$ & $1.33 \mathrm{~b} \pm 0.02$ & $1.22 \mathrm{~b} \pm 0.01$ & $1.47 \mathrm{a} \pm 0.01$ & $\begin{array}{c}\mathrm{F}(3 ; 8)=25.717 \\
p<0.001, \text { Tukey HSD }\end{array}$ \\
\hline$\underset{\% \mathrm{DM}}{\text { Rosmarinic acid }}$ & $3.12 \mathrm{a} \pm 0.26$ & $3.59 \mathrm{a} \pm 0.16$ & $3.83 \mathrm{a} \pm 0.41$ & $3.17 \mathrm{a} \pm 0.36$ & $\begin{array}{c}\mathrm{F}(3 ; 8)=3.595 \\
p=0.066\end{array}$ \\
\hline $\begin{array}{l}\text { Total phenolic content } \\
\text { mg GAE g-1 DM }\end{array}$ & $146.45 \mathrm{a} \pm 9.19$ & $149.71 \mathrm{a} \pm 17.06$ & $105.93 \mathrm{~b} \pm 9.60$ & $178.10 \mathrm{a} \pm 44.17$ & $\begin{aligned} & \mathrm{F}(3 ; 32)=13.128, \\
p<0.001, \text { Games-Howel } & \end{aligned}$ \\
\hline $\begin{array}{l}\text { Antioxidant capacity } \\
\text { mg AAE g-1 DM }\end{array}$ & $131.46 b \pm 9.48$ & $138.96 \mathrm{~b} \pm 17.18$ & $66.14 \mathrm{c} \pm 13.51$ & $201.55 \mathrm{a} \pm 27.39$ & $\begin{array}{c}\mathrm{F}(3 ; 32)=83.737, \\
p<0.001, \text { Games-Howel }\end{array}$ \\
\hline
\end{tabular}

Note. QE - isoquercitroside equivalent, DM - dry mass, GAE - gallic acid equivalent, AAE - ascorbic acid equivalent; different letters in rows are for significantly different groups.

Similarly to the total phenolic content, the highest antioxidant capacity was measured under the continuous drought conditions (treatment stress3) while in the other samples a reduced capacity could be detected. Antioxidant capacity of the control and stress 1 treatments was $53 \%$ and $45 \%$ lower, respectively, while the values of treatment stress 2 were only one third of those of the stress 3 plants. A significant positive correlation $(r=0.880, p<0.000)$ was detected between antioxidant capacity and total phenolic content. Formerly Manukyan (2011) reported a significant increase of the polyphenols (from $1.08 \mathrm{mM}$ to $1.75 \mathrm{mM}$ GAE) of lemon balm leaves in the drought conditions.

\section{Conclusions}

1. The water supply may induce remarkable changes in the morphology, productivity and phytochemical constituents of lemon balm (Melissa officinalis L.). Significant effect of water deficiency was detected on the plant height and diameter, biomass production, number of branches, internode length, root:shoot ratio, flavonoid and total phenolic content, antioxidant capacity. Most marked differences were detected in the plants which were grown under the continuous, long term drought conditions (stress 3 plants responded to the water shortage with decreased biomass production (64\% reduction compared to the control) and the antioxidant capacity of the cells was significantly elevated (by 50\% compared to the control) as a defence reaction.

2. The measured parameters in plants which suffered a gradually decreasing water level (stress 1 ) of the soil showed only moderate changes $(40 \%$ biomass reduction and 5\% elevation in antioxidant capacity). In this treatment, during the thirteen weeks of the experiment a short-term adaptation was observed. This transition phase was expressed in the slightly decreased biomass production while the increased accumulation of phenolic compounds was not detected.

3. In the treatment, where the drought rapidly appeared after a longer well-watered period, the "exhaustion stage" was observed on the plants. They could reach a relatively large biomass (38\% less than the control); however, a significant drop was observed in the concentrations of flavonoid content $(21 \%$ reduction compared to the control), total phenolic content $(29 \%$ reduction) and in antioxidant capacity (50\% reduction). It may be concluded that in this case a further, ongoing drought would result either in total exhaustion and devastation or in survival by adaptation. For this latter situation a decrease of the foliage surface and increase of root mass might be necessary as found in treatment stress 3 .

\section{Acknowledgements}

The work was supported by OTKA Scientific Foundation (No. NN108633).

Received 28062016 Accepted 17102016

\section{References}

Abbaszadeh B., Farahani H. A., Morteza E. 2009. Effects of irrigation levels on essential oil of balm (Melissa officinalis L.). American-Eurasian Journal of Sustainable Agriculture, 3 (3): 53-56

Abdelrahman R. A., Gabr A. M. M., Al-Sayed H. M. A., Smetanska I. 2012. Effect of drought and salinity stress on total phenolic, flavonoids and flavonols contents and antioxidant activity in in vitro sprout cultures of garden cress (Lepidium sativum). Journal of Applied Sciences Research, 8 (8): 3934-3942

Ahl H. A. A. S., Abdou M. A. A., Omer E. A. 2009. Effect of potassium fertilizer on lemon balm (Melissa officinalis L.) grown under water stress conditions. Journal of Medicinal Food Plants, 1 (2): 16-29

Barros L., Duenas M., Dias M. I., Sousa M. J., Santos-Buelga C., Ferreira I. C. F. R. 2013. Phenolic profiles of cultivated, in vitro cultured and commercial samples of Melissa officinalis $\mathrm{L}$. infusions. Fond Chemistry 136: 1-8 http://dx.doi.org/10.1016/j.foodchem.2012.07.107

Bartholy J., Bozó, L., Haszpra, L. 2011. Klímaváltozás 2011. Klímaszcenáriók a Kárpát-medence térségére (in Hungarian)

Benzie I. F., Strain J. J. 1996. The ferric reduction ability of plasma (FRAP) as a measure of ,Antioxidant Power": the FR AP assav. Analvtical Binchemistry. 239: 70-76 http://dx.doi.org/10.1006/abio.1996.0292

Carnat A. P., Carnat A. Fraisse D., Lamaison J. L. 1998. The aromatic and polyphenolic composition of lemon balm (Melissa officinalis L. subsp. officinalis) tea. Pharmaceutica Acta Helvetiae 77: 301-305 http://dx.doi.org/10.1016/S0031-6865(97)00026-5

Chen Y., Gou Q., Liu L., Liao L., Zhu Z. 2011. Intluence of fertilization and drought stress on the growth and production of secondary metabolites in Prunella vulgaris L. Journal of Medicinal Plants Research, 5 (9): 1749-1755

Dastmalchi K., Dorman H. J. D., Oionen P., Darwis Y., Laakso I., Hiltunen R. 2008. Chemical composition and in vitro antioxidative activity of a lemonbalm (Melissa officinalis L.) extract. LWT - Food Science and Technology, 41: 391-400

Dias M. I., Barros L., Sousa M. J., Ferreira I. C. F. R. 2012. Systematic comparison of nutraceuticals and antioxidant potential of cultivated, in vitro cultured and commercial Melissa officinalis samples. Fond and Chemical Toxicolngy, 50: 1866-1873 http://dx.doi.org/10.1016/j.fct.2012.03.057

Duda S. C., Mărgithas L. A., Dezmirean D., Duda M., Mărgăoan R., Bobiş O. 2015. Changes in major bioactive compounds with antioxidant activity of Agastache foeniculum, Lavandula angustifolia, Melissa officinalis and Nepeta cataria: effect of harvest time and plant species. Industrial Crons and Products, 77-499-507 http://dx.doi.org/10.1016/j.indcrop.2015.09.045

Farahanı H. A., Valadabadi S. A., Daneshian J., Kvalvati M. A. 2009. Evaluation changing of essential oil of balm (Melissa officinalis L.) under water deficit stress conditions. Journal of Medicinal Plants Research, 3 (5): 329-333

Hack H., Bleiholder H., Buhr L., Meier U., Schnock-Fricke U., Weber E., Witzenberger A. 1992. Einheitliche Codierung der phänologischen Entwicklungsstadien mono- und dikotyler Pflanzen - Erweiterte BBCH-Skala, Allgemein. Nachrichtenblatt des Deutschen Pflanzenschutzdienstes, 44: 265-270 (in German) 
Halimeh R., Mahlagh G., Maryam P., Pazoki A. 2013. Effect of drought interactions with ascorbate on some biochemical parameters and antioxidant enzymes activities in Dracocephalum moldavica L. Middle-East Journal of Scientific Research, 13 (4): 522-531

Liu H., Wang X., Wang D., Zou Z., Liang Z. 2011. Effect of drought stress on growth and accumulation of active constituents in Salvia miltiorrhiza Bunge. Industrial Crops and Products $33 \cdot 84-88$ http://dx.doi.org/10.1016/j.indcrop.2010.09.006

Manukyan A. 2011. Ettect of growing factors on productivity and quality of lemon catmint, lemon balm and sage under soilless greenhouse production: I. Drought stress. Medicinal and Aromatic Plant Science and Biotechnology, 5 (2): 119-125

Mimica-Dukic N., Bozin B., Sokovic M., Simin N. 2004. Antimicrobial and antioxidant activities of Melissa officinalis L. (Lamiaceae) essential oil. Journal of A gricultural and Fond Chemistry, 52 (9): 2485-2489 http://dx.doi.org/10.1021/jf0306 98 a

Munne-Bosch S., Alegre L. 1999. Kole of dew on the recovery of water-stressed Melissa officinalis L. plants. Journal of Plant Physiolngy 154(5-6). 759-766 http://dx.doi.org/10.1016/S0176-1617(99)80255-7

Nasab A. K., Yarnıa M., Lebashcy M. H., Mırshekarı B., Rejali F. 2015. The response of drought stressed lemon balm (Melissa officinalis L.) to vermicompost and PGPR. Biological Forum - An International Journal, 7 (1): 1336-1344

Ozturk A., Unlukara A., Ipek A., Gurbuz B. 2004. Effects of salt stress and water deficit on plant growth and essential oil content of lemon balm (Melissa officinalis L.). Pakistan Journal of Botany, 36 (4): 787-792

Patora J., Majda T., Gora J., Klimek B. 2003. Variability in the content and composition of essential oil from lemon balm (Melissa officinalis L.) cultivated in Poland. Acta Poloniae Pharmaceutica, 60 (5): 395-400

Pharmacopoeia Europaea VIII. 2013. Melissa leaf. European Directorate for the Quality of Medicines and Health Care, Strasbourg, p. 1318

ISSN 1392-3196 / e-ISSN 2335-8947

Zemdirbyste-Agriculture, vol. 103, No. 4 (2016), p. 385-390

DOI 10.13080/z-a.2016.103.049

\title{
Aprūpinimas vandeniu turi didelès įtakos vaistinès melisos (Melissa officinalis L.) derliui ir jo kokybei
}

\author{
P. Radácsi, K. Szabó, D. Szabó, E. Trócsányi, É. Németh-Zámbori
}

Szent István universitetas, Vengrija

\section{Santrauka}

Tyrimo tikslas - ištirti dirvožemio vandens kiekio ir lietinimo laiko ịtaką veislès 'Soroksár' vaistinès melisos derliaus kiekiui ir cheminèms savybėms. Kontroliniame variante buvo palaikoma $70 \%$ dirvožemio vandens talpa. Bandymo variantuose dirvožemio vandens talpa buvo mažinama dviem būdais: palaipsniui nuo 70 iki 30 \% (1asis itampos atvejis) ir staiga nuo 70 iki 30 \% (2-asis itampos atvejis). Didžiausio vandens trūkumo atveju (3-asis itampos atvejis) buvo nuolat palaikoma $30 \%$ vandens talpa. Vandens trūkumas sumažino derliaus rodiklius: augalo aukštị, žalią bei sausą masę, krūmo lapijos skersmenị, bet padidino šaknies ir ūglio masès santykị, tačiau esminių šaknies ilgio, žalios ir sausos masès pakitimų neịvyko. Vandens trūkumas turèjo ịtakos fenolinių junginių kiekiui. Flavonoidu kaupimasis 1-uoju ir 2-uoju įtampos atvejais sumažèjo 14-22 \%, o 3-iuoju atveju rozmarino rūgšties koncentracija padidejo 1-22\%, palyginus su kontroliniu variantu. Didžiausia antioksidaciné geba (201 mg askorbo rūgšties ekvivalento $\mathrm{g}^{-1}$ sausos masès) ir bendrasis fenoliu kiekis (178 mg galo rūgšties ekvivalento $\mathrm{g}^{-1}$ sausos masès) buvo nustatyti augalams visą laiką augant $30 \%$ vandens talpos dirvožemyje. Mažiausiomis antioksidacine geba (66 mg askorbo rūgšties ekvivalento $\left.\mathrm{g}^{-1}\right)$ ir bendraja fenolių koncentracija (105 mg galo rūgšties ekvivalento $\mathrm{g}^{-1}$ ) pasižymėjo 2-ojo ịtampos atvejo augalai. Palaipsniui mažèjantis apsirūpinimas vandeniu (1-asis įtampos atvejis) nepakeitè nè vieno šiu rodikliu (antioksidacinès gebos ir bendrojo fenoliu kiekio), palyginus su kontroliniu variantu. Tyrimo rezultatai rodo, kad vaistinès melisos derliaus dydžiui ir jo kokybei didelès įtakos gali turèti ne tik dirvožemio vandens trūkumo dydis, bet ir lietinimo laikas bei jo kaitos pobūdis.

Reikšminiai žodžiai: antioksidacinė geba, bendrasis fenolių kiekis, flavonoidai, rozmarino rūgštis, sausra, vaistiniai augalai, vandens trūkumas.

Please use the following format when citing the article:

Radacsi P., Szabo K., Szabo D., Trocsanyi E., Nemeth-Zambori E. Effect of water deficit on yield and quality of lemon balm (Melissa officinalis L.). Zemdirbyste-Agriculture, 103 (4): 385-390 DOI 10.13080/z-a.2016.103.049 